\title{
Synthesis of amberlite XAD-2-ANSA resin for separation, preconcentration and spectrophotometric determination of trace elements in food samples
}

\author{
Mohamed Muthana Taher \\ Department of Chemistry, Faculty of Science and Education, Aden University, Aden, Yemen
}

\begin{abstract}
A new chelating sorbent has been synthesized using Amberlite XAD-2 resin functionalized with 1-amino2-naphthol-4-sulfonic acid (ANSA) through $-\mathrm{N}=\mathrm{N}$ - group. This sorbent, characterized by infrared (FTIR) spectra and optimized for sorption-desorption of the studied metal ions then, it was used as packing for the column for separation/ preconcentration of cadmium, cobalt, and nickel prior to their determination spectrophotometrically. Metal ions of $\mathrm{Cd}, \mathrm{Ni}$, and Co sorbed in the column were eluted one by one with $0.02 \mathrm{M}, 0.10 \mathrm{M}$, and $0.20 \mathrm{M} \mathrm{HCl}$ acid respectively. Under the optimal conditions, the proposed procedure enabled the determination of $\mathrm{Cd}$, $\mathrm{Co}$, and $\mathrm{Ni}$ with detection limits of $0.98,0.30$ and $2.10 \mu \mathrm{g} \mathrm{L}-1$ respectively. The developed procedure was evaluated by the analysis of mixed metal ions $\mathrm{Cd}, \mathrm{Co}$ and $\mathrm{Ni}$ solution contained $0.30,30$, and $1.25 \mu \mathrm{g}$ respectively, and the percentage recovery was $95.5-104 \%$. The procedure was applied to the analysis of food samples (grains of Sorghum bicolor), and the results obtained were compared with that of FAAS (before and after separation/preconcentration).
\end{abstract}

Keywords: Amberlite resin, Synthesis, Analysis, Food.

* Correspondence | Mohamed M. Taher; Department of Chemistry, Faculty of Science and Education, Aden University, Aden, Yemen. Email: mdmuthtaher@gmail.com

Citation | Mohamed MT. 2018. Synthesis of amberlite XAD-2-ANSA resin for separation, preconcentration and spectrophotometric determination of trace elements in food samples. Arch Pharm Sci ASU 2(2): 138-151

DOI: $10.21608 /$ aps.2018.18741

Online ISSN: 2356-8380. Print ISSN: 2356-8399.

Received 21 July 2018. Accepted 11 September 2018.

Copyright: ${ }^{{ }} 2018$ Taher. This is an open-access article licensed under a Creative Commons Attribution 4.0 International License (CC BY 4.0), which permits unrestricted use, distribution, and reproduction in any medium, provided the original author(s) and source are credited

Published by: Ain Shams University, Faculty of Pharmacy

\section{INTRODUCTION}

Different heavy metals of different samples have been determined, after different preconcentration systems, using different analytical instruments. Cadmium has been determined in river water using visible spectrophotometer (Vis-S) after solid phase extraction [1]; Cadmium and Copper have been determined using FAAS after solid phase extraction [2]; Cobalt using Vis-S after solid phase extraction [3]; Nickel using Vis-S after solid phase extraction [4]; cobalt, copper, and nickel using FAAS after solid phase extraction [5]; lead, Cadmium, Nickel, and Cobalt using ICP-AES and ICP-MS after solid phase extraction [6].

Many studies, after solid phase preconcentration, performed an additional 
preconcentration step, this carried out by reducing the volume of eluate, by evaporation, before measuring using FAAS [7, 8]. However, such this additional step is likely to contribute to loss or contamination and to increase in analysis time and chemicals to be used. Some studies have determined heavy metal by flow injection i.e., online preconcentration and determination [9-11]. However, such this system maybe complex, if compared with the off-line system, and on-line is not applicable when there are difficulties to perform the separation/preconcentration and the measurement in the same laboratory. In addition, the off-line system gives options to measure with more than one instrument.

Modern instruments such as ICP-MS, ETAAS or ICP-AES, are more sensitive than FAAS. ETAAS is very expensive, needs a separation and preconcentration procedure [12], and the chemical interference effects are often more severe with electrothermal atomization than with flame atomization [13]. ICP-AES does not have sufficiently high sensitivity than FAAS.

The most widely used separation and preconcentration methods are solid-phase extraction [14], liquid-liquid extraction [15], coprecipitation [16], ion exchange [17], electrochemical deposition [18], membrane filtration [19] and cloud point extraction [20].

Solid phase extraction has advantages over the other widely technique used for separation/ preconcentration of heavy metals traces. These advantages include simplicity, high enrichment factor, regeneration easiness, and significant reducing the disposal costs and extraction time [21].

The most supporting materials used in the solid phase are Silica gel [22, 23], polyurethane [24], and organic co-polymer resins [25]. Among the solid phase, support materials are Amberlite $\mathrm{XAD}$ resins. This type of resins has good physical properties such as high surface area and uniform pore size distribution [26].

Preconcentration using chelating resins have some advantages such as good selectivity, preconcentation factor, binding energy mechanical stability, and easy regeneration [27]. Chelating resins with amines are preferred [28].

The most important and recently reported chelating matrices using Amberlite XAD supports were different according to the ligands and the ways they loaded by. Some of them are Amberlite XAD-2 modified: by pyrocatechol through $-\mathrm{N}=\mathrm{N}-$ group [29], by 2-(methylthio) aniline through $-\mathrm{N}=\mathrm{N}-$ group [30], by 2aminoacetylthiophenol (AATP) [31]. Amberlite XAD-2 resin has been functionalized with others ligands as 4, 5-dihydroxy-1, 3-benzenedisulfonic acid through $-\mathrm{CH}_{2}$ group [32], o-aminophenol through $-\mathrm{N}=\mathrm{N}-$ group [33], pyrocatecholviolt through $-\mathrm{N}=\mathrm{N}-$ group [34].

\section{MATERIALS AND METHODS}

\subsection{Chemicals and reagents}

All chemicals and reagents used were analytical reagent grade and used without previous purification.

\subsection{Instruments and equipment}

Spectronic 20, Milton Roy Company (USA). UV-Visible Specord 200, Analytik Jena AG (Germany). Vista MPX CCP Simltaneous ICPAES Instrument, Varian. Atomic absorption spectromerer 6800, Shimadzu, Japan. Microwave digester, Milestone, Microwave Laboratory System, Ethos Touch Control, N. America.

Stopped flasks, $100 \mathrm{~mL}$ capacity were used in batch sorption experiments. Glass columns of about $25 \mathrm{~cm}$ length and 0.5-0.6 cm internal diameter with stopcock were used in column mode. 


\subsection{Spectrophotometric (Vis-S) determination of heavy metal ions}

Each $\mathrm{M}^{2+}$ ion was determined using Vis-S according to the procedure described in the literature [35]. The absorbance of $\mathrm{Cd}^{2+}$ was measured $(556 \mathrm{~nm})$ at $\mathrm{pH} 10$ using 5-Br-PADAP $(0.02 \%$ in ethanol) as a reagent. The absorbance of $\mathrm{Co}^{2+}$ was measured $(586 \mathrm{~nm})$ at $\mathrm{pH} 7$ using 5Br-PADAP $(0.03 \%$ in DMF) as a reagent. The absorbance of $\mathrm{Ni}^{2+}$ was measured $(558 \mathrm{~nm})$ at $\mathrm{pH}$ 5.5 using 5-Br-PADAP (0.02\% in ethanol) as a reagent.

\subsection{Synthesis of the chelating resin}

According to literature researches [36-38], 15 $\mathrm{g}$ of Amberlite XAD-2 resin were treated with a mixture consisting of $75 \mathrm{~mL}$ conc. $\mathrm{H}_{2} \mathrm{SO}_{4}$ acid and $30 \mathrm{~mL}$ of conc. $\mathrm{HNO}_{3}$ acid. The mixture was placed on a water bath at $60{ }^{\circ} \mathrm{C}$ for $1 \mathrm{hr}$ with continuous stirring. Then it was poured into a mixture of ice-cold water. Thereafter the nitro resin was filtered and washed with DDW until become free of acid traces.

Nitro resin was mixed, in a rounded bottom flask, with $60 \mathrm{~g} \mathrm{SnCl}_{2}, 67 \mathrm{~mL}$ conc. $\mathrm{HCl}$ and 75 $\mathrm{mL}$ ethanol. The mixture was refluxed at $90{ }^{\circ} \mathrm{C}$ for $12 \mathrm{~h}$, filtered, washed with DDW and then with $2 \mathrm{M} \mathrm{NaOH}$. The amino resin was washed with $2 \mathrm{M} \mathrm{HCl}$, then with DDW. The amino resin was suspended in $200 \mathrm{~mL}$ ice-cold water, then treated with portions each of $2 \mathrm{~mL} 1 \mathrm{M} \mathrm{NaNO}_{2}$ and $2 \mathrm{~mL} 1 \mathrm{M} \mathrm{HCl}$ acid until a dark blue color with a starch iodine paper obtained, then it filtered and washed with ice-cold water. Diazotized resin was treated with a solution made up of 5.0 g ligand 1-amino-2-naphthol-4sulphonic acid (ANSA) in $8 \%$ solution of $\mathrm{NaOH}$ at $0-5{ }^{\circ} \mathrm{C}$ for $36 \mathrm{~h}$. The produced chelating resin was filtered, washed with DDW until washes become colorless and, finally, it washed with methanol and air-dried.

\subsection{IR spectra of the prepared new chelating resin (ChR12)}

The IR spectra of the prepared new stationary phase and compounds of different preparation stages were recorded using FTIR according to the procedure mentioned in literature [39]. The data obtained and its interpretations will be present in the section of results and discussion.

\subsection{Optimization of ChR12 for sorption- desorption of metal ions}

\subsubsection{Batch mode}

In a 100-mL stopped flask, $0.1 \mathrm{~g}$ ChR12 was shaken, at room temperature, with $25.0 \mathrm{~mL}$ aqueous solution of each tested metal ions. Resin material was separated. The amount of metal ion remained in the aqueous phase was determined using Vis-S. The percentage extraction (\% E) was calculated by the equation: $\% \mathbf{E}=\left(\mathbf{C}_{\mathbf{0}}-\mathbf{C} / \mathbf{C}_{\mathbf{0}}\right)$ $\times 100$ Where $\mathrm{Co}$ and $\mathrm{C}$ are the concentrations of metal ion before and after extraction, respectively. Effect of $\mathrm{pH}$ was studied in batch mode at $10 \mathrm{mg} / \mathrm{L}$ of each tested metal ion, which adjusted at different $\mathrm{pH}$ values. Effect of shaking time was studied in batch mode at $10 \mathrm{mg} / \mathrm{L}$ of each tested metal ion, which adjusted at optimal $\mathrm{pH}$ value. Effect of initial metal ion concentration (Ci) was studied in batch mode at varied $\mathrm{Ci}$ of each tested metal ion, which adjusted at optimal $\mathrm{pH}$ value.

\subsubsection{Colum mode}

In this present study glass column of $25 \mathrm{~cm}$ length and 0.5-0.6 cm i.d., with stop cock and a small piece of glass wool, was used.

\section{RESULTS \& DISCUSSION}

3.1. Characterization of the Synthesized
Chelating Resin (ChR12) and $\mathrm{M}^{2+}-$
Retaining ChR12


The recorded infrared spectra were used to confirm the introduction of $-\mathrm{NH}_{2}$ group into the skeleton of the plain (Ambelite XAD-2 copolymer resin) and then coupled with chelating ligand 1-amino-2-naphthole-4sulfonic acid (ANSA). Infrared spectra were recorded for the plain, nitrated, and reduced nitrated and finally ligand-coupled-resin. The recorded IR spectra of these four types are shown in Fig. 1. As seen from this figure, there are three distinct infrared vibration bands. The first one band at (1555- 1485, $1355-1320 \mathrm{~cm}^{-1}$ ), confirming the introduction of the $\mathrm{NO}_{2}$ group to the skeleton of the plain because of the nitration processes. The second is the disappearance of some these bands assigned to the $-\mathrm{NO}_{2}$ group (band at 1555$1485,1355-1320 \mathrm{~cm}^{-1}$ ), which others were sharply reduced (1480 and $\left.1335 \mathrm{~cm}^{-1}\right)$ showing a high reduction percentage was performed during the reduction processes. On the other hand, the clear formation of a new sharp band due to the reduction of $-\mathrm{NO}_{2}$ group and characteristic to the $-\mathrm{NH}_{2}$ group was recorded at $3443 \mathrm{~cm}^{-1}$ confirming the previous observation related to the $-\mathrm{NO}_{2}$ group. The third is the appearance (in the ligand-coupled resin) of azo group peak at $\left(\approx 1585 \mathrm{~cm}^{-1}\right)$, C- S peak at $\left(\approx 684 \mathrm{~cm}^{-1}\right)$ and $-\mathrm{OH}$ group peak at $(\approx$ $1319 \mathrm{~cm}^{-1}$ ), confirming the diazotization and the coupling with ligands (1-amino-2naphthol-4-sulphonic acid). Moreover, the interaction of ligands in the new phase leads to a distinct color change (dark brown) which is no longer obtained with the parent phase. There are some similar IR spectral features have been described in the literature [40-44]. IR spectra, from Table 1, demonstrate metal ions retention on $\mathrm{ChR} 12$. It is clear that most of the bands of $\mathrm{M}^{2+}$ - free $\mathrm{ChR} 12$ have undergone changes in their features due to metal retention. There is a similarity between some of these changes and between changes that have been observed and described in many literature types of research [43-46].

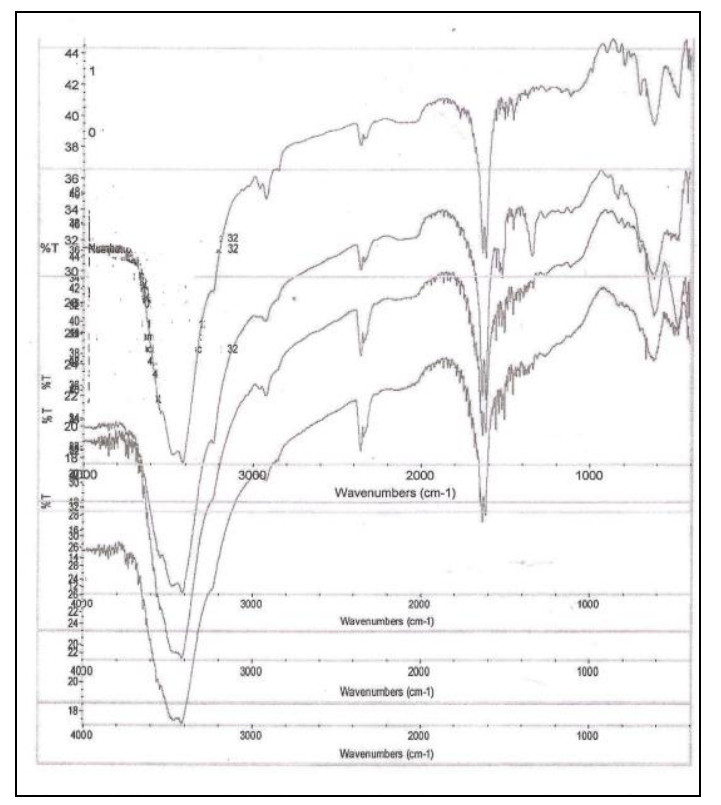

Fig. 1. IR spectra of Amberlite XAD-2 at Different stages of ChR12 synthesis

\subsection{Effect of different parameters on extraction efficiency of metal ions}

The effect of $\mathrm{pH}$ on the extraction of $\mathrm{Cd}^{2+}$, $\mathrm{Co}^{2+}$, and $\mathrm{NI}^{2+}$ ions, by the newly prepared stationary phase ChR12, has been critically investigated. The obtained results are summarized in Fig. 2a-c. It is obvious from these curves that the percentage extraction increases with increasing $\mathrm{pH}$ value from 3 to $8-9$ for all studied metal ions. It has been observed that there is a maximum percentage of extraction at $\mathrm{pH} 8-9$ for all studied metal ions. 
Table 1. Spectral data of the observed infrared vibrational frequencies of $\mathrm{M}^{2+}-$ free $\mathrm{ChR} 12$ and $\mathrm{M}^{2+}-$ retaining ChR12

\begin{tabular}{|c|c|c|c|c|c|c|c|c|c|c|}
\hline Compound & $\begin{array}{c}\text { Phenolic } \\
\text { v(O-H) }\end{array}$ & $\begin{array}{c}\text { Primay } \\
\text { amine } \\
v(N-H)\end{array}$ & $\begin{array}{c}\text { Phenolic } \\
\text { v(C-O) }\end{array}$ & $\overline{\mathrm{N}}=\mathrm{N}-$ & $\begin{array}{c}\text { Primary } \\
\text { amine } \\
(\mathrm{N}-\mathrm{H}) \\
\text { bending }\end{array}$ & $\begin{array}{c}\text { Ar-S } \\
\mathbf{v}(C- \\
S)\end{array}$ & $\begin{array}{c}\text { Phenolic } \\
\text { (O-H) } \\
\text { bending }\end{array}$ & M-O & M-N & $\begin{array}{c}\text { M-N } \\
\text { azo }\end{array}$ \\
\hline $\begin{array}{l}\mathrm{M}^{2+} \text {-free } \\
\text { ChR12 resin }\end{array}$ & $\begin{array}{l}3614- \\
3230\end{array}$ & $\begin{array}{l}3464, \\
3443\end{array}$ & 1197 & 1585 & 1656 & 684 & 1319 & - & - & - \\
\hline $\begin{array}{l}\mathrm{Co}^{2+}{ }_{-} \mathrm{ChR} 12 \\
\text { resin }\end{array}$ & $\begin{array}{c}3565- \\
3230\end{array}$ & 3454 & 1202 & 1574 & 1645 & 684 & 1330 & 528 & 492 & 471 \\
\hline $\begin{array}{l}\mathrm{Ni}^{2+}{ }_{-} \mathrm{ChR} 12 \\
\text { resin }\end{array}$ & $\begin{array}{c}3563- \\
3227\end{array}$ & 3448 & 1204 & 1574 & 1645 & 684 & 1341 & 551 & 525 & 468 \\
\hline
\end{tabular}

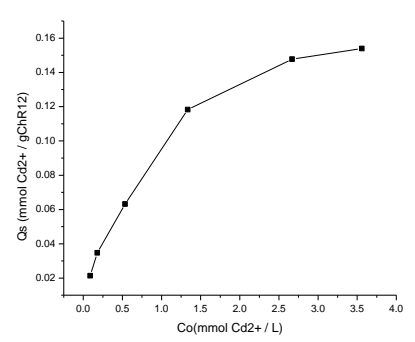

Fig. 2a. Effect of $\mathrm{pH}$ on extraction of $\mathrm{Cd}^{2+}$ ion

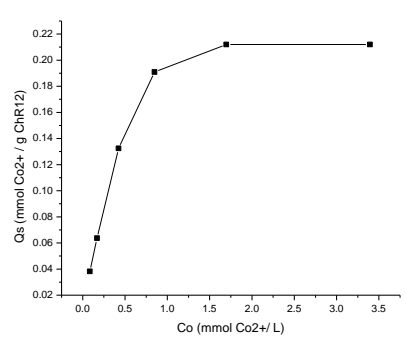

Fig. 2b. Effect of $\mathrm{pH}$ on extraction of $\mathrm{Co}^{2+}$ ion

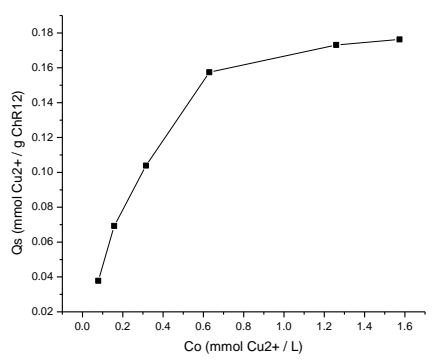

Fig. 2c. Effect of $\mathrm{pH}$ on extraction of $\mathrm{Ni}^{2+}$ ion

\subsection{Effect of extraction time and sorption kinetics.}

The loading rate of $\mathrm{Cd}^{2+}, \mathrm{Co}^{2+}$, and $\mathrm{Ni}^{2+}$ ions on ChR12 resin was studied in batch mode at optimal $\mathrm{pH}$ value and shaking for different periods (10-120 $\mathrm{min})$ at about $25{ }^{\circ} \mathrm{C}$. The sorption kinetics of the metal ions is shown in Table 2. It was observed that the shaking time required to reach equilibrium state were $60-120$ min for $73-80 \% \mathrm{E}$ of $\mathrm{Cd}^{2+}, 20-30$ min for 99 $100 \% \mathrm{E}$ of $\mathrm{Co}^{2+}$ and $60-120$ min for $86-98 \% \mathrm{E}$ of $\mathrm{Ni}^{2+}$. However, all of the studied metal ions were of very good sorption rates. The good rates of extraction of the studied metal ions with ChR12 resin may indicate good accessibility of metal ions to one or more chelating sites $(\mathrm{OH},-$ $\mathrm{N}=\mathrm{N}-$ or $\mathrm{NH}_{2}$ ). 
The loading half time $t_{1 / 2}$ which is defined as the time required for reaching $50 \%$ of the total uptake, was estimated. The Lagregren firstorder rate equation is the simplest rate equation for the sorption in liquid/solid system based on solid capacity [47], dqt/t $=\mathrm{k}_{1}$ (qe-qt) where $\mathrm{k}_{1}$ is the equilibrium rate constant of first-order $(1 / \mathrm{min}), \mathrm{qe}(\mu \mathrm{g} / \mathrm{g})$ is the amount $(\mu \mathrm{g})$ of metal ions sorbed, with one gram of sorbent (ChR12), at equilibrium, and $\mathrm{qt}(\mu \mathrm{g} / \mathrm{g})$ is the amount $(\mu \mathrm{g})$ of metal ions sorbed, with one gram of sorbent (ChR12), at any time t. Integrating this Equation, for the boundary conditions $\mathrm{t}=0$ to $\mathrm{t}$ and $\mathrm{qt}=0$ to $\mathrm{qt}$, yields $\log (\mathrm{qe}-\mathrm{qt})=\log (\mathrm{qe})$ $\left(\mathrm{k}_{1} / 2.303\right)$ t. Plotting $\log$ (qe-qt) versus $\mathrm{t}$ gives a straight line and, therefore, slope $=-\mathrm{k}_{1} / 2.303$, and $\mathrm{t}_{1 / 2}=0.693 / \mathrm{k}_{1}$. Lagregren plot for $\mathrm{Cd}^{2+}, \mathrm{Co}^{2+}$ and $\mathrm{Ni}^{2+}$ are shown in figure 3.8.a-c. The values for $\mathrm{k}_{1}$ and $\mathrm{t}_{1 / 2}$ are found in Table 3 .

Table 2. Effect of shacking time on extraction efficiency

\begin{tabular}{|c|c|c|c|c|c|}
\hline \multicolumn{2}{|c|}{ Cd $^{2+}$} & \multicolumn{2}{c|}{ Co $^{2+}$} & \multicolumn{2}{c|}{ Ni $^{2+}$} \\
\hline $\begin{array}{c}\text { Shaking } \\
\text { Time } \\
(\text { min) }\end{array}$ & $\%$ E & $\begin{array}{c}\text { Shaking } \\
\text { Time } \\
(\text { min) }\end{array}$ & $\%$ E & $\begin{array}{c}\text { Shaking } \\
\text { Time } \\
(\text { min })\end{array}$ & $\%$ E \\
\hline 10 & 46.7 & 10 & 81.5 & 10 & 48.3 \\
\hline 20 & 60.0 & 20 & 98.8 & 25 & 67.5 \\
\hline 30 & 66.7 & 30 & 100 & 35 & 78.3 \\
\hline 60 & 73.0 & 40 & 100 & 55 & 85.8 \\
\hline 120 & 80.0 & 60 & 100 & 120 & 97.5 \\
\hline- & - & - & - & 180 & 93.3 \\
\hline
\end{tabular}

Table 3. kinetic data from Lagregren plot with $\mathrm{Ch}$ $\mathrm{R} 12$ at $25{ }^{\circ} \mathrm{C}$

\begin{tabular}{|c|c|c|c|}
\hline No. & $\mathbf{M}^{2+}$ & $\mathbf{K}_{\mathbf{1}}\left(\mathbf{m i n}^{-\mathbf{1}}\right)$ & $\mathbf{t}_{\mathbf{1} / \mathbf{2}}(\mathbf{m i n})$ \\
\hline 1 & $\mathrm{Cd}^{2+}$ & 0.03 & 23.1 \\
\hline 2 & $\mathrm{Co}^{2+}$ & 0.069 & 10.0 \\
\hline 4 & $\mathrm{Ni}^{2+}$ & 0.03 & 23.1 \\
\hline
\end{tabular}

\subsection{Effect of initial concentration (Ci) on} Static Sorption capacity (Qs) of ChR12

The sorption capacity of metal ions was studied by batch mode at different initial concentration $C_{i}(\mathrm{mmol} / \mathrm{L})$ solution at optimal $\mathrm{pH}$ and shaking time. The total sorption capacity Qs (mmol/g ChR12) was calculated using the equation:

Qs $(\mathrm{mmol} / \mathrm{g}$ ChR 12$)=\mathrm{C}_{\mathrm{i}} / \mathrm{m}=\left[\left(\% \mathrm{E} * \mathrm{C}_{0} *\right.\right.$ $\mathrm{V}) / \mathrm{mol} \mathrm{wt}.] / \mathrm{m}$

Where $\mathrm{C}_{\mathbf{0}}$ is the initial concentration $(\mathrm{mg} / \mathrm{L})$, $\mathrm{V}$ is the sample volume (L) of the metal concentration $\mathrm{C}_{0}$, mol wt. is the weight of mole atoms of the metal, and $m$ is the weight of ChR12 (g). Fig. 3a-c, show the effect of the initial concentration $\left(\mathrm{C}_{\mathrm{i}}\right)$ on static sorption of $\mathrm{ChR} 12$ for $\mathrm{Cd}^{2+}, \mathrm{Co}^{2+}$ and $\mathrm{Ni}^{2+}$ respectively. The calculated total static capacity (Qs) at a higher initial concentration $\left(C_{i}\right)$ are summarized in Table 4. These results show that ChR12 has sufficient high Qs for the studied metal ions. $\mathrm{Co}^{2+}$ and $\mathrm{Ni}^{2+}$ ions appeared to have higher affinity than $\mathrm{Cd}^{2+}$ to be sorbed with ChR12 and their approximate capacity is 0.20 whereas of $\mathrm{Cd}^{2+}$ ion is $0.15 \mathrm{mmol} / \mathrm{g} \mathrm{ChR} 12$. 
Table 4. Total static capacities of ChR12 for different metal ions

\begin{tabular}{|c|c|c|c|}
\hline No. & Metal ions & $\mathbf{C}_{\mathbf{i}} \mathbf{~ m m o l} / \mathbf{L}$ & $\begin{array}{c}\text { Qs mmol/g } \\
\text { ChR12 resin }\end{array}$ \\
\hline 1 & $\mathrm{Cd}^{2+}$ & 3.599 & 0.154 \\
\hline 2 & $\mathrm{Co}^{2+}$ & 3.393 & 0.212 \\
\hline 4 & $\mathrm{Ni}^{2+}$ & 5.110 & 0.220 \\
\hline
\end{tabular}

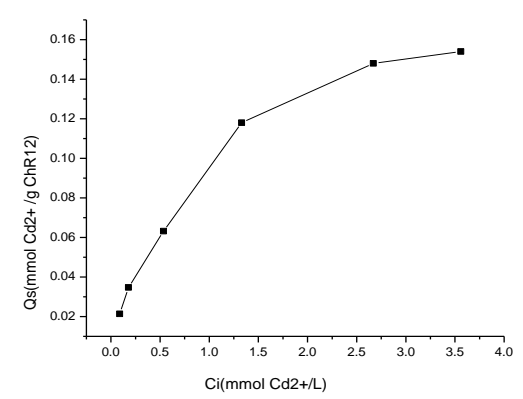

Fig. 3a. The static capacity of ChR12 at different $C_{i}$ of $\mathrm{Cd}^{2+}$ ions.

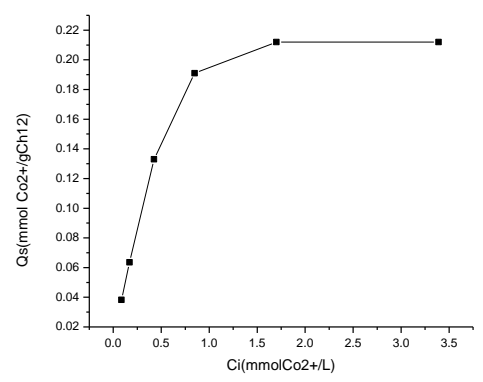

Fig. 3b. The static capacity of ChR12 at different $C_{i}$ of $\mathrm{Co}^{2+}$ ions

\subsection{Effect of sample flow rate on sorption of metal ions with ChR12}

The influence of sample flow rate on the sorption of each metal ion with $\mathrm{ChR} 12$ was studied by percolating, at $0.5-4.5 \mathrm{~mL} \mathrm{~min}^{-1}$ flow rate, $25 \mathrm{~mL} 10 \mathrm{mg} / \mathrm{L}$ metal ion solution at optimal $\mathrm{pH}$ value and, finally, measuring the remains in the effluents by Vis-S. The retention profiles of the elements to the ChR12 at different sample flow rates are depicted in Fig.

4.

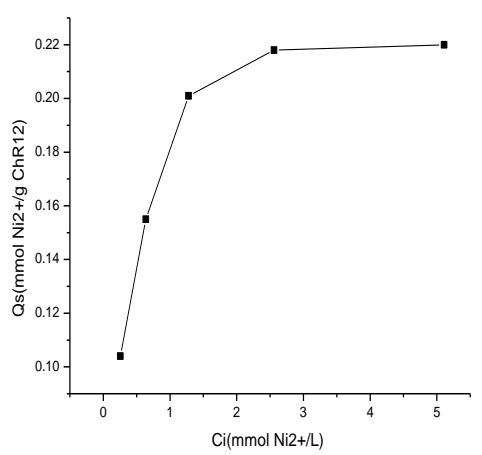

Fig. 3c. The static capacity of ChR 12 at different $C_{i}$ of $\mathrm{Ni}^{2+}$ ions.

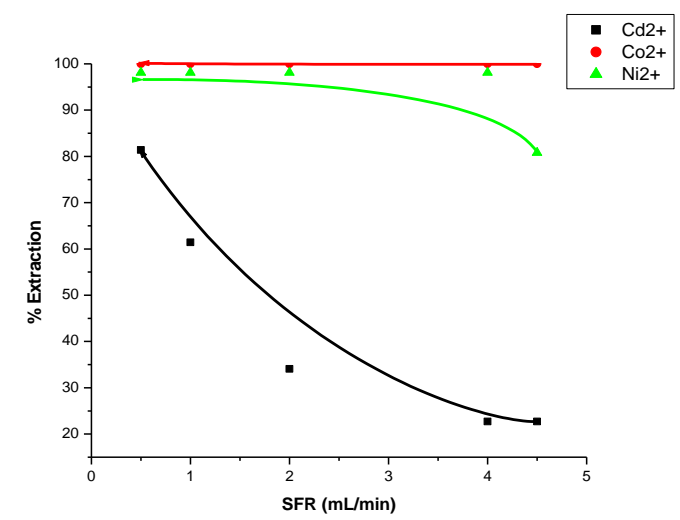

Fig. 4. Effect of Solution Flow rate on Sorption of metal ions with $\mathrm{ChR} 12$

The obtained results indicated that the optimum flow rate for quantitative metal ions retention is about $2 \mathrm{~mL} \mathrm{~min}^{-1}$ or less for $\mathrm{Co}^{2+}$ and $\mathrm{Ni}^{2+}$, and about $0.6 \mathrm{~mL} \mathrm{~min}^{-1}$ for $\mathrm{Cd}^{2+}$. The later one metal ion exhibited its need for a long contact time to reach adequate equilibration

\subsection{Breakthrough curve and dynamic capacity (Qd)}

A break-through curve is obtained by plotting column effluent concentration versus 
volume treated or time of treatment. Breakthrough point is defined as the time when the cation of the feed first appears in the effluent [48]. Furthermore, the volume of solution percolated from the breakthrough point to the point of leveling of the loading curve for a given solution flow rate also depends upon the kinetics of exchange [49]. The breakthrough curve of each $\mathrm{M}^{2+}$ ion was carried out by percolating, up ChR12 saturation, a suitable volume of metal ions at optimal condition and, finally, measuring the remains concentration in the effluents. Fig. 5. depict breakthrough curves of $\mathrm{Cd}^{2+}, \mathrm{Co}^{2+}$ and $\mathrm{Ni}^{2+}$ ions. Breakthrough capacity (mmol $\mathrm{g}^{-1} \mathrm{ChR} 12$ ) was calculated according to the equation [50]:

dynamic capacity $=\left(\mathrm{V} 50 \% * \mathrm{C}_{\mathrm{o}}\right) / \mathrm{m}$

and dividing by 1000, the equation becomes:

dynamic capacity $=\left[\left(\mathrm{V} 50 \% * \mathrm{C}_{\mathrm{o}}\right) / \mathrm{m}\right] / 1000$

where $\mathrm{V} 50 \%$ is the effluent volume $(\mathrm{mL})$ at $50 \%$ breakthrough, $C_{\mathrm{o}}$ is the concentration of the influent solution $\left(\mu \mathrm{mol} \mathrm{mL} L^{-1}\right)$, and $\mathrm{m}$ is the mass (g) of ChR12. Breakthrough and dynamic capacities $\left(\mathrm{mmol} \mathrm{g}^{-1}\right)$ for the studied metal ions are listed in Table 5. Breakthrough capacities for all of the studied metal ions are lower than their dynamic capacities. This is normal as the breakthrough capacity is calculated at throughput volume i.e., at first detection of metal ions in the effluent, whereas dynamic capacity is calculated at $50 \%$ breakthrough. Dynamic Capacities for all of the studied metal ions are lower than their Static (batch) Capacities. This is also usual and it relies on several parameters such as the column bed height, sample flow rate, temperature of the solution, particle size, and concentration of the feeding solution [49]. High linear velocity may result in premature breakthrough [51]. In addition, the difference between static and dynamic capacities of a particular metal ion depends on the required time for binding with the chelating sites. From Table 4, and Table 5, it is seen that there is no large difference between the static and dynamic capacity for $\mathrm{Co}^{2+}$ and $\mathrm{Ni}^{2+}$ whereas this difference is too large for $\mathrm{Cd}^{2+}$, this maybe because that $\mathrm{Cd}^{2+}$ ion needs longer contact time for binding in the chelating sites.

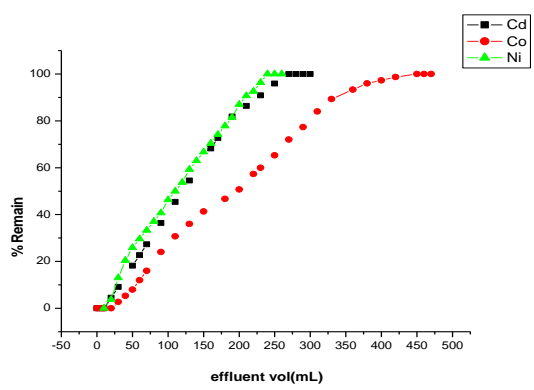

Fig. 5. Breakthrough curves of studied metal ions.

Table 5. Breakthrough and dynamic capacities

\begin{tabular}{|l|c|c|c|c|c|}
\hline $\mathbf{M}^{2+}$ & $\mathbf{p H}$ & $\begin{array}{c}\text { Flow } \\
\text { rate } \\
\mathbf{m L} / \mathbf{m i n} .\end{array}$ & $\begin{array}{c}\text { Q.b } \\
\mathbf{m m o l} \mathbf{g}^{-1}\end{array}$ & $\begin{array}{c}\text { Q.d } \\
\mathbf{m m o l ~ g}\end{array}$ & $\begin{array}{c}\boldsymbol{C}_{\mathbf{~}} \\
\mathbf{m m o l} / \mathbf{m L}\end{array}$ \\
\hline $\mathrm{Cd}^{2+}$ & 5.5 & 0.6 & 0.00468 & 0.0281 & 0.08897 \\
\hline $\mathrm{Co}^{2+}$ & 9 & 2 & 0.0303 & 0.192 & 0.424 \\
\hline $\mathrm{Ni}^{2+}$ & 8.5 & 1 & 0.0269 & 0.148 & 0.511 \\
\hline
\end{tabular}

\subsection{Effect of the eluting agent on elution of metal ions}

Elution step is one of important solid phase extraction steps and, here, in this present study, elution gains additional importance and interest since this study, in it's the main part, aimed for determining toxic heavy metals using analytical instruments of good availability as Vis-S and FAAS. So, wide varieties of eluting agents 
types, concentration and flow rate were examined for each metal ion. The important results we got for a particular eluting agent, are depicted in one figure for comparison purpose. From Fig. 6a, it is obvious that the eluting agent $0.5 \mathrm{M} \mathrm{HCl}$ acid can elute all of the studied metal ions. From Fig. 6b, it is clear that $0.5 \mathrm{M}$ $\mathrm{HCl}$ acid in acetone can elute $\mathrm{Cd}^{2+}$ and $\mathrm{Co}^{2+}$, but cannot elute $\mathrm{Ni}^{2+}$. From Fig. 6c, $1 \mathrm{M} \mathrm{HNO}_{3}$ acid can elute $\mathrm{Cd}^{2+}, \mathrm{Ni}^{2+}$ quantitatively, and $\mathrm{Co}^{2+}$ partially. From Fig. 6d and e, 0.2 M Tartaric acid at $\mathrm{pH}=3$ and $0.3 \mathrm{M}$ Tartaric at $\mathrm{pH}=5$ acetate can elute $\mathrm{Cd}^{2+}$ quantitatively, and $\mathrm{Co}^{2+}$ and $\mathrm{Ni}^{2+}$ partially. From Fig. 6f, $3.12 \mathrm{~g}$ and 3.12. $\mathrm{h}, 0.02,0.03$ and $0.05 \mathrm{M} \mathrm{HCl}$ acid can elute $\mathrm{Cd}^{2+}$ but cannot elute $\mathrm{Ni}^{2+}$ and $\mathrm{Co}^{2+}$. From Fig. 6i, $0.1 \mathrm{M} \mathrm{HCl}$ acid can elute $\mathrm{Cd}^{2+}$ and $\mathrm{Ni}^{2+}$ but cannot elute $\mathrm{Co}^{2+}$. From Fig. 6j, $0.2 \mathrm{M} \mathrm{HCl}$ acid can elute $\mathrm{Cd}^{2+}, \mathrm{Ni}^{2+}$ and $\mathrm{Co}^{2+}$. From the above observations, $\mathrm{Cd}^{2+}$ can be eluted an alone firstly with $0.02 \mathrm{M} \mathrm{HCl} . \mathrm{Ni}^{2+}$ can be eluted an alone secondly with $0.1 \mathrm{M} \mathrm{HCl} . \mathrm{Co}^{2+}$ can be eluted an alone thirdly with $0.2 \mathrm{M} \mathrm{HCl}$.

\subsection{Evaluation and application of the Developed Separation/preconcentration Procedure}

Validation must always be carried out for newly developed or modified procedures. This can take place either by comparison of the results of the analyses with those of a validated or an independent analytical procedure or by analysis of reference materials or of control samples prepared in the laboratory itself [52]. The procedure TTEST (one tail, two tails) can be used for two results comparison [151].

In this present study, the developed separation-preconcentration method has been evaluated and validated by analysis of metals mixture solution and analysis of food samples (grains of sorghum bicolor) and results in comparison with results of another instrument as follows:

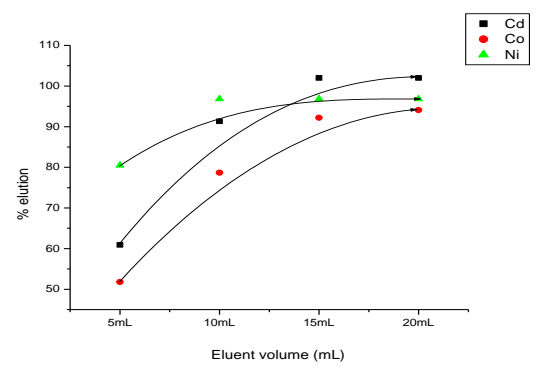

Fig. 6a. Effect of $0.5 \mathrm{M} \mathrm{HCl}$ acid on elution of metal ions

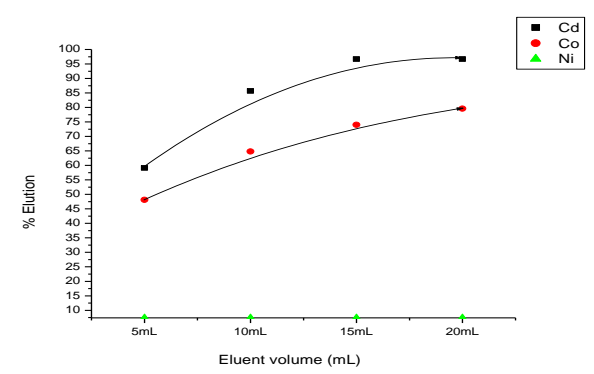

Fig. 6b. Effect of $0.5 \mathrm{M} \mathrm{HCl}$ acid in acetone on elution of metal ions

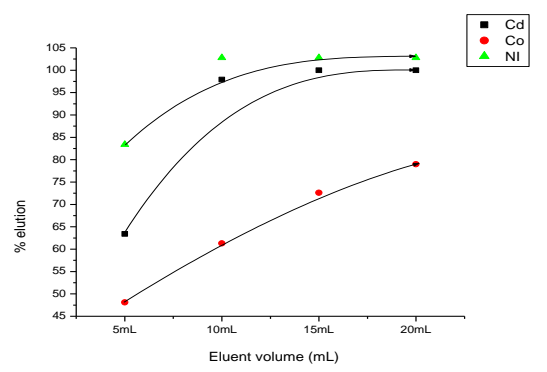

Fig. 6c. Effect of $1 \mathrm{M} \mathrm{HNO}_{3}$ acid acid on elution of metal ions 


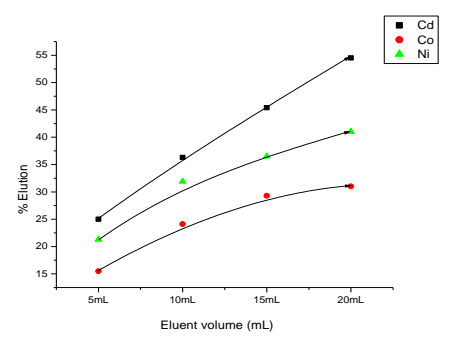

Fig. 6d. Effect of $0.2 \mathrm{M}$ Tartaric acid $\mathrm{pH}=3$ Acetate on elution of metal ions

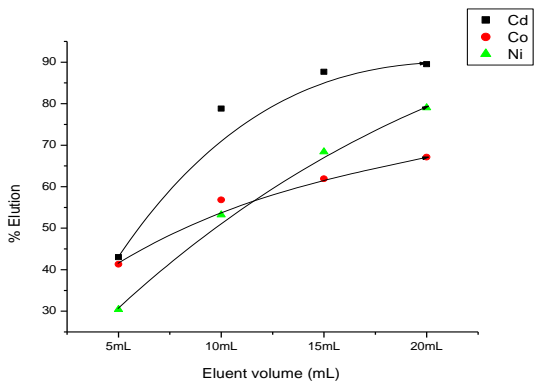

Fig. 6e. Effect of $0.3 \mathrm{M}$ Tartaric acid $\mathrm{pH}=5$ Acetate on elution of metal ions

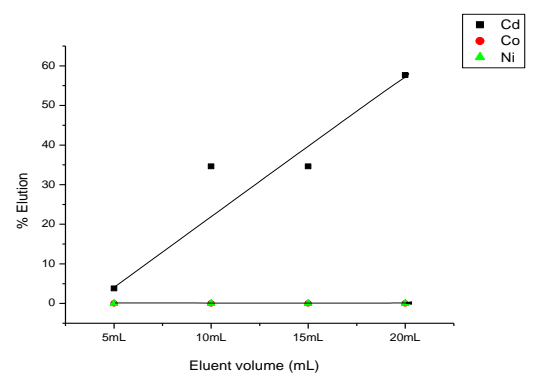

Fig. 6f. Effect $0.0 .02 \mathrm{M} \mathrm{HCl}$ acid on elution of metal ions

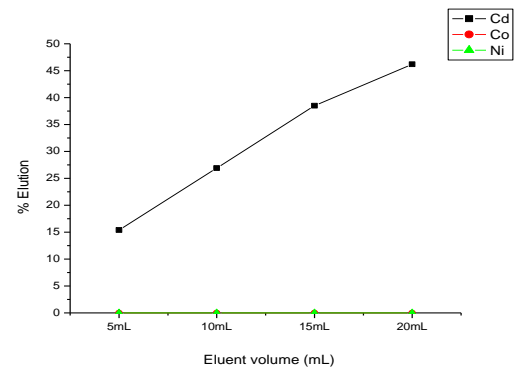

Fig. 6g. Effect of $0.03 \mathrm{M} \mathrm{HCl}$ acid on elution of metal ions

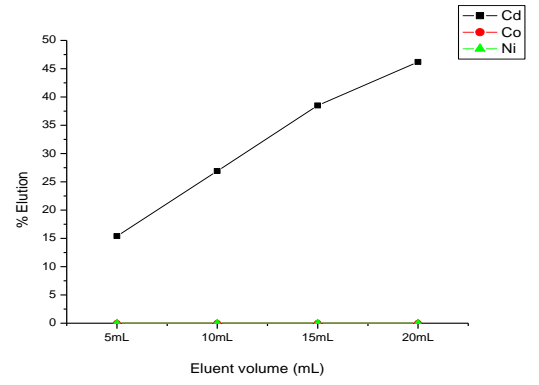

Fig. 6h. Effect of $0.05 \mathrm{M} \mathrm{HCl}$ acid on elution of metal ions

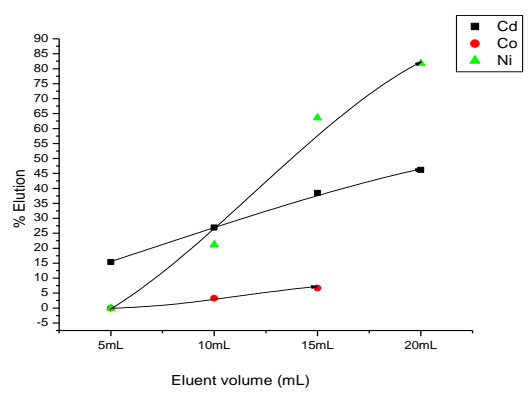

Fig. 6i. Effect of $0.1 \mathrm{M} \mathrm{HCl}$ acid on elution of metal ions

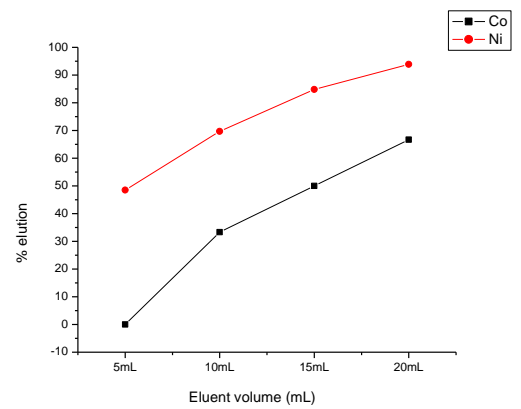

Fig. 6j. Effect of $0.2 \mathrm{M} \mathrm{HCl}$ acid on elution of metal ions

\subsubsection{Separation of mixture metal ions solution}

In order to separate $\mathrm{Cd}^{2+}, \mathrm{Co}^{2+}$ and $\mathrm{Ni}^{2+}$ ions from a mixture using the $\mathrm{ChR} 12$ resin packed in column, the solution containing all metal ions was adjusted to $\mathrm{pH} 8.5$ using buffer solution and suitable masking agents, then the solution was percolated through the column packed with ChR12 resin at flow rate $0.6-0.2 \mathrm{~mL} / \mathrm{min}$, analyses of three replicates were carried out. the 
tested ions were eluted from the column by the suitable eluting agent and, then, determined by Vis-S. The obtained results are summarized in Table 6.

Table 6. Statistical data of the studied metal ions in their mixture solution

\begin{tabular}{|c|c|c|c|c|}
\hline $\mathbf{M}^{2+}$ & $\begin{array}{c}\boldsymbol{\mu g} \\
\text { added }\end{array}$ & $\begin{array}{c}\boldsymbol{\text { m}} \\
\text { mean }\end{array}$ & $\mathbf{R S D}$ & Replicate \\
\hline $\mathrm{Cd}^{2+}$ & 0.3 & 104 & 3.9 & 3 \\
\hline $\mathrm{Co}^{2+}$ & 0.3 & 95.5 & 0.7 & 2 \\
\hline $\mathrm{Ni}^{2+}$ & 1.25 & 97 & 7.2 & 3 \\
\hline
\end{tabular}

From Table 6, it is very clear that the Proposed separation, a method is valid (accurate and precise) for all tested metal ions. Since the $\% \mathrm{R}$ average means were excellent, 104, 95.5 and 97, and the RSD were also very good, 3.9, 0.7 and 7.2 for cadmium, cobalt, and nickel respectively.

3.8.2. Comparison between results of sorghum grains analysis for metal ions content using Vis-S and FAAS

It is clear from Table 7, that the Cadmium analysis result using FAAS (before separation) was less precise as its RSD was somehow high (15.7), $n=1$ whereas those of both Vis-S and FAAS (after separation) were more precise as their RSD were somehow lower (4.1), $n=2$ for FAAS, and (8.2), $n=3$ for Vis-S. In addition, these of Vis-S and FAAS (after separation) are not significantly $(\mathrm{p}, 2$-tails $=0.21)$ different. Nickel analysis results of Vis-S and FAAS (before and after separation) are not significantly $(\mathrm{p}, 2$-tails $=0.10)$ different.

Table 7. Comparison between metal analysis results of sorghum grains using Vis-S, FAAS

\begin{tabular}{|c|c|c|c|c|c|c|c|c|c|}
\hline M & \multicolumn{2}{|c|}{$\begin{array}{c}\text { Spectrophotometer (after } \\
\text { separation) }\end{array}$} & \multicolumn{2}{|c|}{$\begin{array}{c}\text { FAAS } \\
\text { (after separation) }\end{array}$} & \multicolumn{3}{|c|}{$\begin{array}{c}\text { FAAS } \\
\text { (before separation) }\end{array}$} \\
\cline { 2 - 10 } & $\mathbf{C}\left(\boldsymbol{\mu g g}^{-1}\right)$ & $\mathbf{R S D}$ & $\mathbf{n}$ & $\mathbf{C}\left(\boldsymbol{\mu g g}^{-1}\right)$ & $\mathbf{R S D}$ & $\mathbf{n}$ & $\mathbf{C}\left(\boldsymbol{\mu g g}^{-1}\right)$ & $\mathbf{R S D}$ & $\mathbf{n}$ \\
\hline $\mathrm{Cd}$ & 0.2640 & 8.2 & 3 & 0.2880 & 4.1 & 2 & 0.425 & 15.7 & 1 \\
\hline $\mathrm{Co}$ & 0.5293 & 11.2 & 3 & - & - & - & - & - & - \\
\hline $\mathrm{Ni}$ & 2.474 & 2.6 & 3 & 2.850 & 8.2 & 3 & 3.208 & 3.4 & 2 \\
\hline
\end{tabular}

\subsection{Advantages of the newly Developed solid phase Procedure}

From Table 8, it can be concluded that there are similarities in the accuracy $(\% \mathrm{R})$, precision
(RSD) and the metal amounts added to be recovered, between the present developed solid phase Procedure and most of the other preconcentration systems. The advantage of our developed separation/preconcentration 
procedure is that it enables analysis of three important toxic heavy metals $\left(\mathrm{Cd}^{2+}, \mathrm{Co}^{2+}\right.$, and $\mathrm{Ni}^{2+}$ ) using one simple column in a single run, reasonable volumes of gradient low concentration one eluting agent type, and measuring using more than one available and inexpensive Analytical instruments.

Table 8. Comparison between the newly developed solid phase with other preconcentration systems

\begin{tabular}{|c|c|c|c|c|c|c|c|c|}
\hline Preconcentration system & $\begin{array}{c}\text { Studied } \\
\text { metals }\end{array}$ & pH & $\% \mathrm{R}$ & RSD & $\begin{array}{c}\mu g \text { in a } \\
\text { sample of } \\
\text { evaluation }\end{array}$ & $\begin{array}{l}\text { Anal. } \\
\text { Inst. }\end{array}$ & $\begin{array}{l}\text { Sample of } \\
\text { Application }\end{array}$ & Ref. \\
\hline $\begin{array}{l}\text { XAD-2/ 4,5- dihydroxy- } \\
\text { 1,3-benzenedisulfonic acid }\end{array}$ & $\mathrm{Ni}$ & 7.1 & $\begin{array}{l}94- \\
110\end{array}$ & $\begin{array}{l}8.2-2.6 \\
\text { for } \\
0.01- \\
0.2 \\
\end{array}$ & $\begin{array}{c}2-4 \\
\text { Shrimp }\end{array}$ & Vis-S & $\begin{array}{c}\text { Food } \\
\text { (shrimp) }\end{array}$ & 101 \\
\hline $\begin{array}{l}\text { C18/2-(2-quinol la zo)-5- } \\
\text { diethylamin oaniline }\end{array}$ & Co & 5.5 & 94.5 & 2.6 & $\begin{array}{c}2.2 \\
\text { Tea leaf }\end{array}$ & Vis-S & $\begin{array}{l}\text { river, Lake \& } \\
\text { Tap water }\end{array}$ & 39 \\
\hline $\begin{array}{l}\text { XAD-2010/4-Hydroxy } \\
\text { benzaldehyde -4- } \\
\text { bromophenyl hydrazone }\end{array}$ & $\mathrm{Ni}$ & $4 \pm 0.2$ & $\begin{array}{c}98- \\
99\end{array}$ & 0.15 & $\begin{array}{c}0.3 \\
\text { DDW }\end{array}$ & Vis-S & $\begin{array}{c}\text { river, Tap } \\
\text { water, alloys }\end{array}$ & 40 \\
\hline $\begin{array}{l}\text { AmberliteXAD-16/gallic } \\
\text { acid, }\end{array}$ & $\begin{array}{l}\mathrm{Ni}, \\
\mathrm{Cu}, \\
\mathrm{Co}\end{array}$ & $6-7$ & $\begin{array}{c}97.5 \\
97, \\
99.4\end{array}$ & $\begin{array}{r}3.6 \\
2.9 \\
2.3\end{array}$ & $\begin{array}{l}250 \\
\text { river water }\end{array}$ & FAAS & River water & 53 \\
\hline $\begin{array}{l}\text { 1- benzylpiperazine } \\
\text { dithiocarbamate complex }\end{array}$ & $\mathrm{Cd}$ & $4-5$ & 97.6 & 3.6 & $\begin{array}{c}10.0 \\
\text { Deionized } \\
\text { water }\end{array}$ & FAAS & $\begin{array}{c}\text { waters \& } \\
\text { alloys }\end{array}$ & 54 \\
\hline $\begin{array}{l}\text { SDS coated alumina } \\
\text { /indane-1,2,3-trione 1,2- } \\
\text { dioxime }\end{array}$ & $\begin{array}{l}\mathrm{Cu}, \\
\mathrm{Ni} \\
\mathrm{Co}\end{array}$ & 9 & $\begin{array}{l}98.7 \\
96.2 \\
95.0\end{array}$ & $\begin{array}{l}1.8,1.5 \\
1.7\end{array}$ & $\begin{array}{c}10 \\
\text { model soln. }\end{array}$ & FAAS & $\begin{array}{c}\text { water } \\
\text { samples }\end{array}$ & 55 \\
\hline $\begin{array}{l}\text { XAD-2/1-amino-2- } \\
\text { naphthol-4-sulphonic acid }\end{array}$ & $\begin{array}{l}\mathrm{Cd}, \\
\mathrm{Co}, \\
\mathrm{Ni}\end{array}$ & 8.5 & $\begin{array}{c}104 \\
95.5 \\
97\end{array}$ & $\begin{array}{l}3.9 \\
0.7 \\
7.2\end{array}$ & $\begin{array}{c}0.3 \\
0.3, \\
1.25 \\
\text { metal } \\
\text { mixture soln. }\end{array}$ & $\begin{array}{l}\text { Vis-S } \\
\text { and } \\
\text { FAAS }\end{array}$ & $\begin{array}{l}\text { food } \\
\text { (sorghum } \\
\text { grains) }\end{array}$ & $\begin{array}{l}\text { Present } \\
\text { study }\end{array}$ \\
\hline
\end{tabular}

\section{CONCLUSION}

Based on this work, the following conclusions can be illustrated:

The synthesized chelating resin12 (ChR12) is a solid phase capable efficiently to preconcentrate traces of $\mathrm{Cd}^{2+}, \mathrm{Co}^{2+}$ and $\mathrm{Ni}^{2+}$ ions from a reasonable volume of sample solution using applicable one simple column.

The developed procedure is suitable for determination of $\mathrm{Cd}^{2+}, \mathrm{Co}^{2+}$ and $\mathrm{Ni}^{2+}$ ions using low sensitive and inexpensive analytical instruments. 
Analyses results of our developed separation/ preconcentration method using Vis-S were comparable to that of high sensitivity analytical instruments.

The developed procedure has advantages since it involves working on three important toxic metals, using one column simultaneous extraction and separative elution, reasonable volumes of gradient low concentration one eluent type, and measuring using available analytical instruments as Vis-S, FAAS; these advantages are not together involved in another separation/preconcentration method according to our good knowldgement.

Separation and/or preconcentration is important in trace determination of cadmium and lead regardless of the sensitivity of the instrument to be used.

\section{Conflict of interest}

The author declares that there are no conflicts of interest.

\section{REFERENCES}

1. F. Ashrafi, A. M. Attaran, N. M. Kermani; Journal of the Korean Chemical Society 52, 2 (2008) 133-139

2. V. A. Lemos, P. X. Baliza; Talanta 67 (2005) 464

3. Q. Hu, G. Yang, X. Dong, J.Yin; Turk J Chem 28 (2004) 611

4. D. Rekha, J. D. Kumar, B. Jayaraj, Y. Lingappa, P. Chiranjeevi; Bull. Korean Chem Soc 28 (2007) 367.

5. V. A. Lemos, G. T. D avid, L. N. Santos; Braz.chem.soc.17 4 (2006) 697-704

6. T. Sumida, T. Nakazato, H. Tao, M. Oshima, S. Motomizo; Anal. Sci. 22 (2006) 1163.

7. M. Soylak, A. U. Karatepe; Turk J Chem. 27 (2003) 235 $-242$

8. H. Bag, A. Elci, L. Elci; Eurasian J Analytic. Chem. 1, 1 (2006) 42-54

9. C. B. Ojeda, F. S. Rojas, J.M. C. Pavón, A. G. de Torres; Analytica Chimica Acta 494 (2003) 97-103
10. Z. F. Queiroz, F. R.P. Rocha, G. Knapp, F. J. Krug, Analytica Chimica Acta 463 (2002) 275-282

11. K. Oguma, J. Flow Injection Anal. 10, 2 (1993) 173186

12. J. Klamtet, N. Suphrom, C. Wanwat; Mj. Int. J. Sci. Tech. 2 (2008) 408-417

13. D. A. Skoog, D. M. West, F. J. Holler, S. R. Crouch; Brooks /Cole- Thomson Learning (2004) 865.

14. E. A. Moawed, M. A. Zaid, M. F. El-Shahat; Acta Chromatographica, 15, (2005) $220-237$

15. F. S. Rojas, C. B. Ojeda, J.M. Pavon; European Scientific Journal 9, 12 (2013) 1857 - 7881

16. S. Saracoglu, M. Soylak, L. Elci; Talanta 59 (2003) $287-293$

17. B. Mandal, N. Ghosh; Indian Journal of Chemistry 48A (2009) 668-671

18. N. M. Najafi, P. Shakeri, E. Ghasemi; Chemistry and Chemical Engineering 17, 2, (2010) 144-151

19. B. Ya. Spivakov', V. M. Shkinev, K. E. Geckeler; Pure Appl Chem 66, 3 (1999) 631-640.

20. P. Biparva, M. R. Hadjmohammadi; Acta Chim. Slov. 54 (2007) 805-810

21. A. Gundogdu, C. Duran, H. B. Senturk, L. Elci, M. Soylak, Acta Chim. Slov., 54, (2007), 308

22. Wu. Yimei, Z. Zhiui; FENXI HUAXUE (Analytical Chemistry) 18, 10 (1990) 925-928

23. W. X. Ma, F. Liu, K. A. Li, W. Chen, S. Y. Tong, Analytica Chimica Acta 416 (2000) 191-196

24. S. Arpadjan, P. Petrova, J. Knutsson; Eurasian Journal of Analytical Chemistry 3, 1 (2008) 10-18

25. O. Dalman, V. N. Bulut, I. Degirmencioglu, M. Tufekci; Turk J Chem 31 (2007) 631-646

26. V. N. Bulut, A. Gundogdu, C. Duran, H. B. Senturk, M. Soylak, L. Elci, M. Tufekci, J. Haza Mater 146 (2007) 155.

27. C. Duran, H. B. Senturk, L. Elci, M. Soylak, M. Tufekci, J. Haza Mater, 162, 1 (2008) 292-299

28. A. Zagorodni, Elsevier Book Aid International (2007) 30,60

29. P. K. Tewari, A. K. Singh; Talanta 53(2001) 823.

30. Y. Guo, B. Din, Y. Liu, X. Chang, S. Meng, M. Tian; Analytica Chemica Acta 504 (2004) 319. 
31. Y. Guo, B. Din, Y. Liu, X. Chang, S. Meng, J. Liu; Talanta 62 (2004) 209

32. V. A. Lemos, P. X. Baliza; Talanta 66 (2005) 174

33. M. Kumar, D.P.S. Rathore, A. K. Singh; Talanta 51(2000) 1187

34. R. Saxena, A. K. Sing; Analyttica Chemica Acta 340 (1997) 285

35. Z. Marczenko, M. Balcerzak; Elsevier (2000) 135-136, 171-172, 179-180, 241-242, 288

36. V. A. Lemos, J. S. Santos, L. S. Nunes, M. B. de Carvalho, P. X. Baliza, R. T. Yamaki; Analytica Chimica Acta 494 (2003) 87.

37. H. Askun, B. Gülbakan, ö. Celikbıcak, C. Uzun, O. Güven, B. Salih; J. Appl. Polymer Sci. 107 (2008) 2714.

38. D. Wu, A. Wang, L. Guo; Anal. Sci. 22 (2006) 1245.

39. R. J. Anderson, D. J. Bendell, P. W. Groundwater; RSC (2004) 32

40. R. Meyers, John Wiley \& Sons Ltd (2000) 10-15

41. B. A. Shah, A. V. Shah, N. B. Patel; IPJ 17, 1 (2008) 3

42. B. A. Shah, A. V. Shah, P. M. Shah; IPJ 15, 10 (2006) 809

43. I. Demir, M. Bayrakci, K. Mutlu, A. I. Pekacar; Acta Chim. Slov 55 (2008) 120

44. P. Sözen, Y. Akgül, F. Demirhan; Turk J Chem 31 (2007) 201

45. M. Sönmez, Turk J Chem 25 (2001) 181-185

46. G. G. Mohamed, M. M. Omar, A. M. Hindy; Turk J Chem, 30 (2006) 361.

47. T. S. Y. C. Muhammad, T. G. Chuah, R. Yunus, A. R. Suaraya; Jurnal Rekayasa Kimia dan Lingkungan 7, 4 (2010) 149

48. V. J. Inglezakis, M.D. Loizidou, H.P. Grigoropoulou; Water Research 36 (2002) 2784

49. M. E. Malla, M. B. Alvarez, D. A. Batistoni; Talanta 57 (2002) 277

50. N. Simpson, Taylor \& Francis Group LLC (2000) 15

51. A. Kettrup, Wiley-VCH Verlag (2002) 37

52. D. Hibbert, Oxford Press (2007) 35-50

53. R. K. Sharma, P. Pant; J. Haza Mater 163 (2008) 295301
54. H. Cesur, B. Bati; Turk J Chem, 26 (2002), 29 - 35

55. M. Hossein, N. Dalali, A. Karimi, K. Dastanra, Turk J Chem 34 (2010) 805 